\title{
PERANCANGAN STRUKTUR BETON BERTULANG MENGGUNAKAN SOFTWARE STAADPRO V8i
}

\author{
Darmansyah Tjitradi $^{1}$, Eliatun ${ }^{2}$, Hary Afriono ${ }^{3}$ \\ ${ }^{1}$ Staff Pengajar Program Studi Pendidikan Profesi Insinyur Universitas Lambung Mangkurat \\ ${ }^{2}$ Staff Pengajar Program Studi Teknik Sipil Universitas Lambung Mangkurat \\ ${ }^{3}$ Mahasiswa Program Studi Magister Teknik Sipil Universitas Lambung Mangkurat \\ Email: tjitradi_syah@ulm.ac.id
}

\begin{abstract}
ABSTRAK
Dunia konstruksi telah berkembang pesat, khususnya untuk perhitungan analisis dan desain struktur yang telah banyak berkembang menuju penggunaaan software-software aplikasi komputer. Dengan menggunakan software perancangan struktur bangunan terasa lebih cepat, akurat, dan efisien, dibandingan dengan perancangan secara manual yang memerlukan waktu yang sangat lama. Dalam tulisan ini akan dibahas penggunaan software Staadpro V8i dalam perancangan struktur beton bertulang 4 lantai dengan fungsi sebagai gedung perkantoran yang berada pada daerah tanah lunak di kota Banjarmasin Timur. Dengan menggunakan software akan dilakukan kombinasi pembebanan berupa kombinasi antara beban mati, beban hidup, dan beban gempa, sehingga diperoleh gaya yang paling maksimum yang akan digunakan dalam desain elemen struktur. Hasil dari penerapan software Staadpro V8i ini adalah berupa gaya-gaya dalam (gaya momen, lintang, normal), serta deformasi struktur yang terjadi. Selain itu juga diperoleh desain penulangan elemen struktur berupa gambar penulangan lentur dan geser pada setiap elemen struktur (balok dan kolom).
\end{abstract}

Kata kunci: perancangan struktur beton, analisis dan desain struktur, Staadpro V8i

\begin{abstract}
The world of construction is developing rapidly, especially, in terms of structural analysis and design which have been advancing towards the use of computer applications. By utilising such software, the design of building structures has become faster, more accurate, and more efficient than that carried out manually. This paper discusses the use of Staadpro V8i software in the structural design of a 4-storey office building on soft soil in East Banjarmasin. Loading combination is performed to accommodate dead loads and live loads, as well as seismic loading in such a way to determine the maximum force necessary for designing the structural elements. The output includes moments, shear forces, normal forces, and the resulting structural deformation. In addition, the software also produces the reinforcement design of the structural elements in the form of flexural and shear reinforcement drawings for each of the structural members (beams and columns).
\end{abstract}

Keywords: concrete structural design, structural analysis and design, Staadpro V8i 


\section{PENDAHULUAN}

Analisis dan desain struktur suatu bangunan telah mengalami perkembangan yang sangat pesat sekali akibat berkembangnya software-software analisis dan disain struktur. Penggunaan software analisis dan desain struktur dalam perancangan suatu struktur bangunan sangat membantu sekali terutama dalam hal kecepatan analisis gaya-gaya dalam dan efisiensi desain elemen-elemen struktur yang sudah menggunakan peraturan-peraturan terbaru. Sebelum adanya software analisis struktur maka untuk melakukan analisis dan disain suatu struktur gedung bertingkat akan membutuhkan waktu yang sangat lama tetapi dengan adanya software maka analisis dan disain dapat dilakukan dalam hitungan hari bahkan jam, selain itu sangat mudah sekali melakukan optimasi desain elemen-elemen struktur. Secara umum sofware-software analisis dan disain struktur dikembangkan menggunakan konsep dasar yang hampir sama, yaitu konsep analisis struktur menggunakan metode elemen hingga dan metode matriks, sehingga perlu sekali memahami kedua konsep tersebut agar mudah untuk mempelajari software-software tersebut. Software-software analisis dan desain struktur yang banyak digunakan adalah Staadpro V8i, SAP2000, Etabs, SANS/Pro, dll., setiap software memiliki kelebihan dan spesifikasi masing -masing. Hal yang perlu diperhatikan dalam penggunaan software analisis dan disain struktur adalah pemahaman pengguna terhadap pemodelan, konsep analisis dan disain, peraturan (code) yang berlaku dan spesifikasi software. Perlu disadari bahwa software hanyalah merupakan alat bantu (tool), sehingga software akan menghasilkan output sesuai dengan input yang diberikan. Oleh karena itu tujuan dari tulisan ini adalah penggunaan Software Staadpro V8i dalam perancangan struktur beton bertulang dengan berdasarkan peraturan SNI 2847:2019.

\section{METODE PENELITIAN}

Metode penelitian yang digunakan adalah:

1) Studi literatur dilakukan dengan mendalami materi yang relevan dengan penelitian, yang meliputi berbagai buku teks, jurnal ilmiah, peraturan dan Standar Nasional maupun Internasional.

2) Melakukan analisis pembebanan struktur dengan fungsi kantor menurut SNI 1727:2013

3) Membuat permodelan struktur bangunan beton bertulang menggunakan Software Staadpro V8i

4) Mengkaji hasil Software Staadpro V8i berupa gaya-gaya dalam, deformasi, dan desain penulangan elemen struktur balok dan kolom.

5) Membuat kesimpulan sesuai dengan tujuan.

\section{1) Data Mutu Bahan}

Mutu beton $\quad=25 \mathrm{MPa}$

Mutu baja tulangan lentur $=400 \mathrm{MPa}$

Mutu baja tulangan geser $=240 \mathrm{MPa}$

\section{2) Data Geometri struktur}

Dalam kajian ini diambil model struktur beton bertulang 4 lantai dengan fungsi bangunan adalah perkantoran yang berada pada daerah tanah lunak, dengan dimensi balok 30/50, ringbalk 25/35, kolom 30/30, tebal pelat lantai $12 \mathrm{~cm}$, tebal pelat dak $10 \mathrm{~cm}$, seperti pada Gambar 1. 


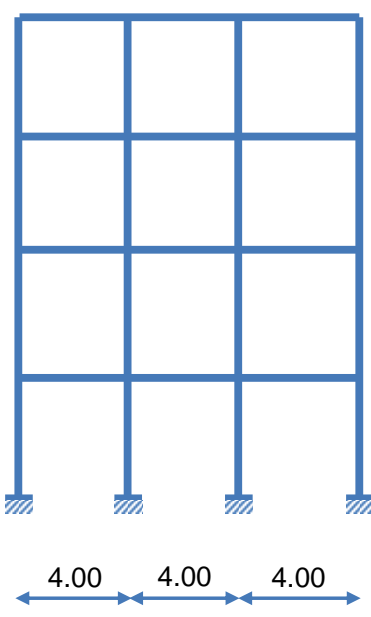

Portal arah X

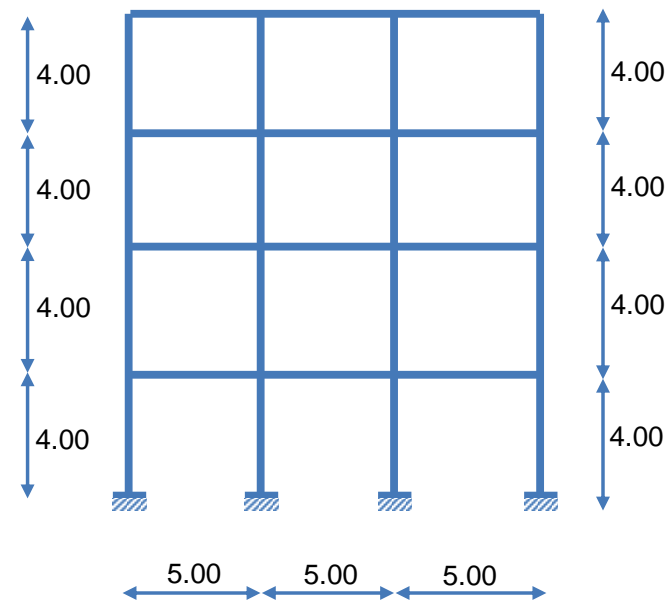

Portal arah Y
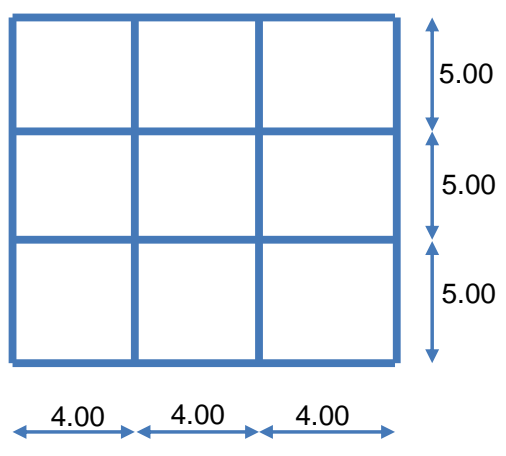

Denah Lantai 1 sd. 4

Gambar 1. Model Struktur beton bertulangan Gedung Perkantoran

\section{HASIL DAN PEMBAHASAN}

\section{1) Analisis Pembebanan Struktur}

Struktur beton bertulang dirancang untuk dapat memikul seluruh beban-beban yang bekerja pada struktur. Beban merupakan gaya luar yang bekerja pada struktur seperti beban mati, beban hidup, dan beban gempa. Beban-beban tersebut nantinya akan dikombinasikan menurut peraturan pembebanan yang berlaku.

Terdapat berbagai pedoman yang mengatur tentang pembebanan di Indonesia:

a) Persyaratan Beton Struktural Untuk Bangunan Gedung (SNI 2847:2019).

b) Tata Cara Perencanaan Ketahanan Gempa Untuk Struktur Bangunan Gedung dan Non Gedung (SNI 1726:2019).

\section{Analisis pembebanan yang bekerja pada portal:}

\section{Analisis Beban Grativasi (Darmansyah T., 2018)}

a. Beban Lantai 1 sd. 3:

Beban yang bekerja pada pelat lantai ini:

\section{Beban Mati:}

- Berat sendiri Pelat Lantai $(\mathrm{tp}=12 \mathrm{~cm})$

- Berat ubin Semen PC+adukan $(24+21)$

$$
\begin{aligned}
=0,12 \times 2400 & =288 \mathrm{~kg} / \mathrm{m}^{2} \\
& =45 \mathrm{~kg} / \mathrm{m}^{2} \\
& =18 \mathrm{~kg} / \mathrm{m}^{2} \\
& =40 \mathrm{~kg} / \mathrm{m}^{2} \\
\text { qDL } & =\mathbf{3 9 1} \mathbf{k g} / \mathbf{m}^{2}
\end{aligned}
$$

- Berat Plafond + penggantung $(11+7)$

- Beban Mekanikal Elektrikal (ME) untuk kantor

\section{Beban Hidup:}

- Beban hidup untuk Kantor

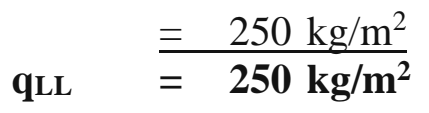

Beban merata yang bekerja pada dinding:

$$
=875 \mathrm{~kg} / \mathrm{m}^{\prime}
$$




\section{b. Beban Lantai Dak:}

Beban yang bekerja pada pelat lantai ini:

Beban Mati:

- Berat sendiri Pelat Lantai $(\mathrm{tp}=10 \mathrm{~cm})$

- Berat Plafond + penggantung $(11+7)$

$$
\begin{array}{rlr}
=0,10 \times 2400 & =240 \mathrm{~kg} / \mathrm{m}^{2} \\
& =18 \mathrm{~kg} / \mathrm{m}^{2} \\
& =40 \mathrm{~kg} / \mathrm{m}^{2} \\
\text { qDL } & =\mathbf{2 9 8} \mathbf{k g} / \mathbf{m}^{2}
\end{array}
$$

- Beban Mekanikal Elektrikal (ME) untuk kantor

Beban Hidup:

- Beban air hujan $(\mathrm{t}=2 \mathrm{~cm})$

- Beban hidup

$$
\begin{aligned}
=0,02 \times 1000 & =20 \mathrm{~kg} / \mathrm{m}^{2} \\
& =100 \mathrm{~kg} / \mathrm{m}^{2} \\
\text { qLL } & =\mathbf{1 2 0} \mathbf{~ k g} / \mathbf{m}^{2}
\end{aligned}
$$

\section{Analisis Beban Gempa}

a. Massa Bangunan

- Lantai 1 sd 3:

Beban Mati:

- Lantai

- Dinding

$$
=12 \times 15 \times 391
$$$$
=70.380
$$

$\mathrm{kg}$

- Balok

$$
=108 \times 875
$$$$
=94.500
$$$$
\mathrm{kg}
$$

- Kolom

$$
\begin{aligned}
& =108 \times 0.30 \times 0.38 \times 2400 \\
& =64 \times 0.30 \times 0.30 \times 2400
\end{aligned}
$$$$
=29.548,800
$$

$=13.824$

\section{Beban Hidup:}

$$
\text { Total-1 }=208.252,800 \mathrm{~kg}
$$

- Reduksi Beban Hidup untuk kantor $=0.30$

- Beban hidup $\quad=0.30 \times 12 \times 15 \times 250$

$$
\begin{aligned}
\text { Total-2 } & =13.500 \quad \mathrm{~kg} \\
\mathbf{m}_{1} & =221.752,800 \mathrm{~kg} \\
\mathbf{m}_{2} & =221.752,800 \mathrm{~kg} \\
\mathbf{m}_{3} & =221,752,800 \mathrm{~kg}
\end{aligned}
$$$$
\text { - Total Massa Lantai-1 }
$$$$
\text { - Total Massa Lantai-2 }
$$$$
\text { - Total Massa Lantai-3 }
$$

\section{- Lantai Dak:}

\section{Beban Mati:}

- Lantai

$$
\begin{array}{rlr}
=12 \times 15 \times 298 & =53.640 \mathrm{~kg} \\
=108 \times 0.25 \times 0.25 \times 2400 & =16.200 \mathrm{~kg} \\
=32 \times 0.30 \times 0.30 \times 2400 & =6.912 \mathrm{~kg} \\
\text { Total-1 } & =\mathbf{7 6 . 7 5 2} \mathbf{~ k g}
\end{array}
$$

- Balok

- Kolom

\section{Beban Hidup:}

- Reduksi Beban Hidup untuk kantor $=0.30$

- Beban hidup $\quad=0.30 \times 12 \times 15 \times 120$

\section{- Total Massa Lantai-4}

$$
\begin{array}{rrrr}
5 \times 120 & = & 6.480 & \mathrm{~kg} \\
\text { Total-2 } & \mathbf{6 . 4 8 0} & \mathbf{k g} \\
\mathbf{m}_{4} & =\mathbf{8 3 . 2 3 2} & \mathbf{k g}
\end{array}
$$

Berat Gedung Total $(W t)=m_{1}+m_{2}+m_{3}+m_{4}=748.490,400 \mathrm{~kg}$ 
Dengan menggunakan peta gempa yang diperoleh secara online pada website http://rsa.ciptakarya.pu.go.id/2021/ (Dirjen Cipta Karya, 2021) akan diperoleh parameter percepatan gempa terpetakan (SS dan S1) pada lokasi pada Banjarmasin Timur dan grafik Respon Spektrum Desain Gempa seperti pada Gambar 2 (Himawan I, dkk., 2013), Finley A. C. (2015).

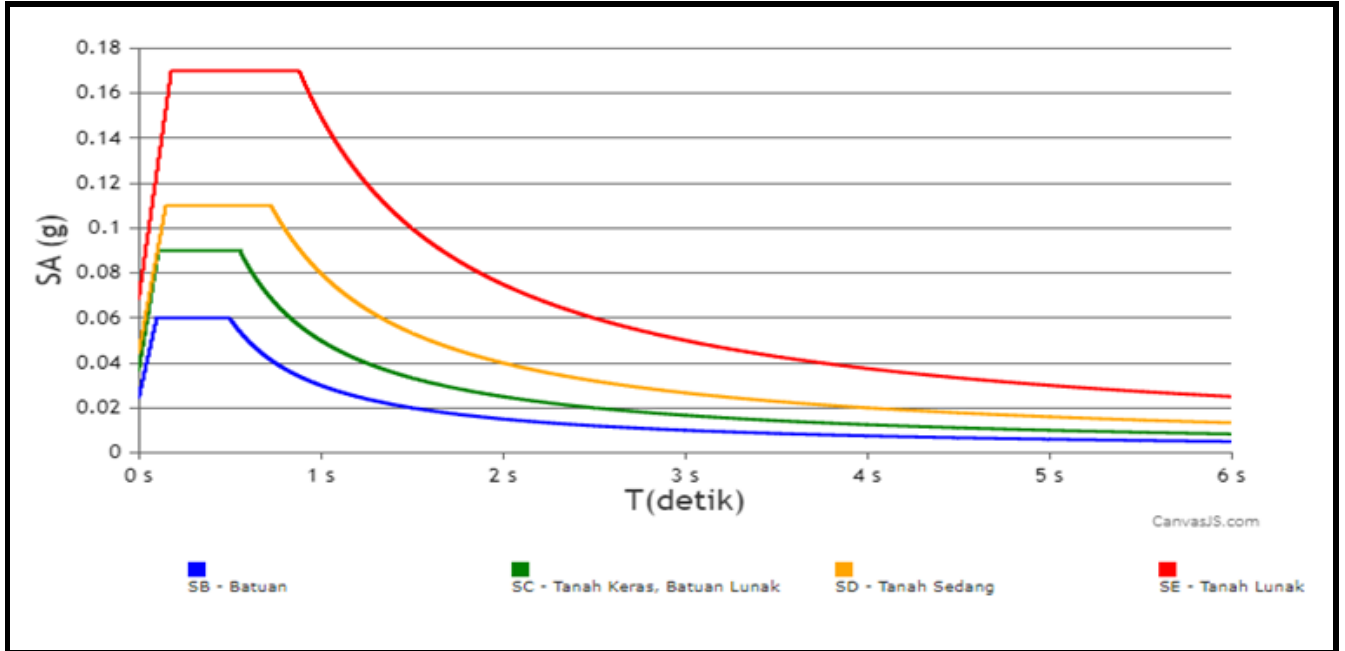

Gambar 2. Grafik Respon Spektrum Desain Gempa

Untuk kondisi Tanah lunak (SE) diperoleh data:

$\mathrm{S}_{\mathrm{S}}=0,1052 \mathrm{~g}$

$\mathrm{S}_{1}=0,0516 \mathrm{~g}$

$\mathrm{S}_{\mathrm{DS}}=0,1662 \mathrm{~g}$

$\mathrm{S}_{\mathrm{D} 1}=0,1500 \mathrm{~g}$

$\mathrm{T}_{\mathrm{S}}=\mathrm{S}_{\mathrm{D} 1} / \mathrm{S}_{\mathrm{DS}}=0,9031$ detik

$\mathrm{T}_{\mathrm{o}}=0,2 \cdot \mathrm{T}_{\mathrm{S}}=0,1838$ detik

$\mathrm{T}_{\mathrm{L}}=12$ detik

Gedung perkantoran termasuk dalam kategori resiko II, sehingga Faktor Keutamaan Struktur : Ie $=1,0$

Koefisien Modifikasi Respon : $\mathrm{R}=5$

Sehingga diperoleh Kategori Desain Seismik $=\mathrm{C}$ dan Sistem Struktur yang diijinkan adalah Sistem Rangka Pemikul Momen Menengah (SRPMM).

Koefisien $\mathrm{Cu}$ diperoleh dari Tabel 17 pada SNI 1726:2019, dengan nilai $\mathrm{S}_{\mathrm{D} 1}=0,15 \mathrm{~g}$, diperoleh $\mathrm{Cu}=1,60$.

Waktu Getar alami $(\mathrm{T}): \mathrm{T}=\mathrm{C}_{\mathrm{u}} \cdot \mathrm{Ta}=1,6 \cdot 0,40=0,64$ detik

Karena $\mathrm{T}<\mathrm{T}_{\mathrm{L}}$ maka:

Koefisien Respons Seismik $(\mathrm{Cs})$ maksimum $=\mathrm{S}_{\mathrm{D} 1} /[\mathrm{T} \cdot(\mathrm{R} / \mathrm{Ie})]=0,15 /(0,64 \cdot(5 / 1))=0,0469$

Koefisien Respons Seismik (Cs) minimum $=0,044 \cdot \mathrm{S}_{\mathrm{DS}} \cdot \mathrm{Ie} \geq 0,01=0,044 \cdot 0,1662 \cdot 1=0,007 \geq 0,01$ diambil 0,01.

Koefisien Respons Seismik (Cs):

$C s=\frac{S_{D S}}{\left(\frac{R}{I e}\right)}=\frac{0,1662}{\left(\frac{5}{1}\right)}=0,0332$

Gaya geser gempa dasar total $(\mathrm{V}): \mathrm{V}=\mathrm{Cs} . \mathrm{Wt}=0,0332 \cdot 748.490 .400=24.849,881 \mathrm{~kg}$ 
Karena jumlah portal arah $\mathrm{X}$ dan $\mathrm{Y}$ sama sebanyak 4 buah maka gaya geser gempa arah $\mathrm{X}$ dan $\mathrm{Y}$ akan sama, yaitu:

Wt dalam arah $X:$ Wtx $=748.490,400 / 4=187.122,600 \mathrm{~kg}$

Wt dalam arah Y : Wty $=748.490,400 / 4=187.122,600 \mathrm{~kg}$

$\mathrm{Vx}=\mathrm{Cs} . \mathrm{Wtx}=0,0332 \cdot 187.122,600=6.212,470 \mathrm{~kg}$

$\mathrm{Vy}=\mathrm{Cs}$. Wty $=0,0332 \cdot 187.122,600=6.212,470 \mathrm{~kg}$

Selanjutnya gaya gempa dasar (V) ini didistribusikan di sepanjang tinggi struktur bangunan gedung menjadi beban-beban gempa statik ekivalen yang bekerja pada pusat massa lantai-lantai tingkat (Adamo Z, 2020).

Beban Horisontal Terpusat arah X dan Y:

$F_{i x}=\frac{W_{i} \cdot h_{i}^{k}}{\sum W_{i} \cdot h_{i}^{k}} \cdot V_{X}$

$F_{i y}=\frac{W_{i} \cdot h_{i}^{k}}{\sum W_{i} \cdot h_{i}^{k}} \cdot V_{Y}$

$\mathrm{k}=$ eksponen yang berhubungan dengan periode getar struktur (yang mempertimbangkan higher mode effects), bernilai 1,0 jika periode getar $\leq 0,5$ detik (yang berarti distribusinya berupa bentuk segitiga, umumnya pada bangunan rendah), dan bernilai 2,0 jika periode getar $\geq 2,5$ detik (yang berarti distribusinya berupa bentuk parabolik, umumnya pada bangunan tinggi). Untuk periode getar diantaranya dapat dilakukan interpolasi.

Untuk $\mathrm{T}=0,64$ detik, dengan interpolasi linear diperoleh nilai $\mathrm{k}=1.070$

$$
\begin{aligned}
& \mathrm{F}_{1 \mathrm{x}}=\mathrm{F}_{1 \mathrm{y}}=\frac{55.438,200 \cdot 4,00^{1,070}}{1.953 .237,411} \cdot 6.212,470=777,902 \mathrm{~kg} \\
& \mathrm{~F}_{2 \mathrm{x}}=\mathrm{F}_{2 \mathrm{y}}=\frac{55.438,200 \cdot 8,00^{1,070}}{1.953 .237,411} \cdot 6.212,470=1.633,154 \mathrm{~kg} \\
& \mathrm{~F}_{3 \mathrm{x}}=\mathrm{F}_{3 \mathrm{y}}=\frac{55.438,200 \cdot 12,00^{1,070}}{1.953 .237,411} \cdot 6.212,470=2.520,256 \mathrm{~kg} \\
& \mathrm{~F}_{4 \mathrm{x}}=\mathrm{F}_{4 \mathrm{y}}=\frac{20.808 \cdot 16,00^{1,070}}{1.953 .237,411} \cdot 6.212,470=1.286,916 \mathrm{~kg}
\end{aligned}
$$

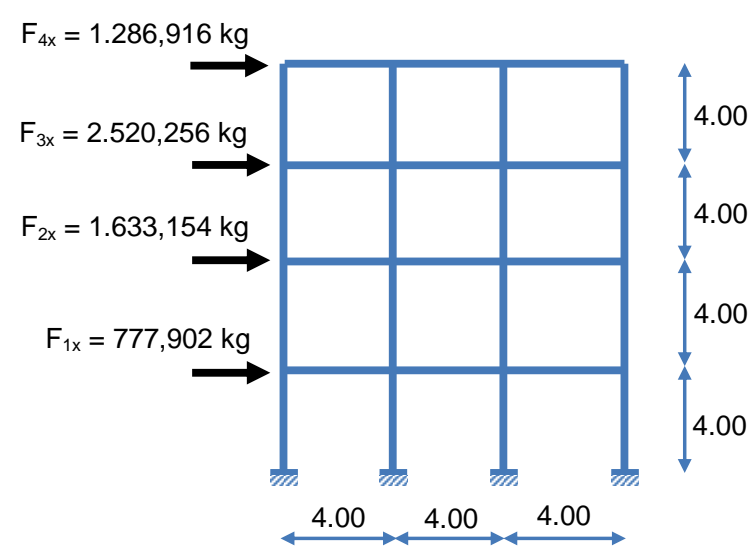

Portal arah X

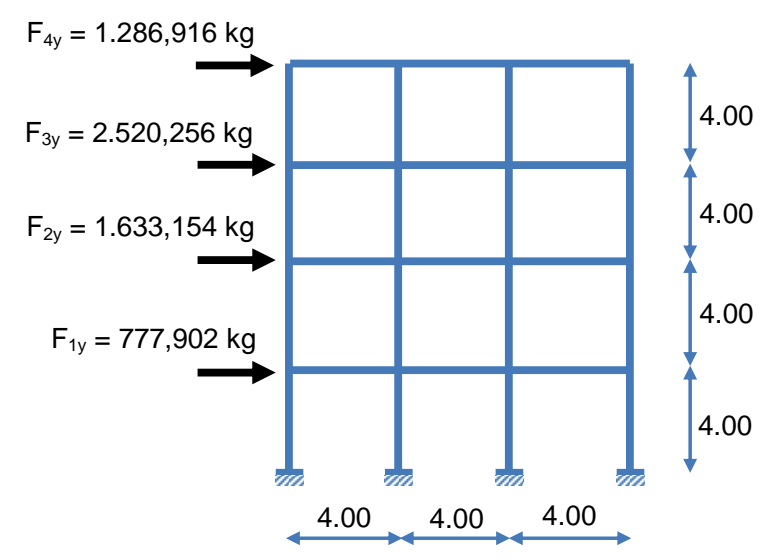

Portal arah Y

Gambar 3. Distribusi Beban Gempa arah X dan Y 


\section{Kombinasi Pembebanan}

Kombinasi pembebanan untuk menganalisis struktur beton bertulang menggunakan peraturan SNI 2847:2019 (Yudha Lesmana, 2020), yaitu:

\section{Beban ultimit:}

$$
\begin{aligned}
& \mathrm{U} 1=1,4 \mathrm{DL} \\
& \mathrm{U} 2=1,2 \mathrm{DL}+1,6 \mathrm{LL} \\
& \mathrm{U} 3=1,2 \mathrm{DL}+1,0 \mathrm{LL} \pm 1,0 \mathrm{EX} \\
& \mathrm{U} 4=1,2 \mathrm{DL}+1,0 \mathrm{LL} \pm 1,0 \mathrm{EY} \\
& \mathrm{U} 5=0,9 \mathrm{DL} \pm 1,0 \mathrm{EX} \\
& \mathrm{U} 6=0,9 \mathrm{DL} \pm 1,0 \mathrm{EY} \\
& \mathrm{U} 7=1,2 \mathrm{DL}+1,0 \mathrm{LL} \pm 1,0 \mathrm{EX} \pm 0,3 \mathrm{EY} \\
& \mathrm{U} 8=1,2 \mathrm{DL}+1,0 \mathrm{LL} \pm 1,0 \mathrm{EY} \pm 0,3 \mathrm{EX}
\end{aligned}
$$

\section{Beban kerja:}

$$
\begin{aligned}
\mathrm{U} 9 & =1,0 \mathrm{DL}+1,0 \mathrm{LL} \\
\mathrm{U} 10 & =1,0 \mathrm{DL}+1,0 \mathrm{LL}+1,0 \mathrm{EX} \\
\mathrm{U} 11 & =1,0 \mathrm{DL}+1,0 \mathrm{LL}+1,0 \mathrm{EY} \\
\mathrm{U} 12 & =1,0 \mathrm{DL}+1,0 \mathrm{LL} \pm 1,0 \mathrm{EX} \pm 0,3 \mathrm{EY} \\
\mathrm{U} 13 & =1,0 \mathrm{DL}+1,0 \mathrm{LL} \pm 1,0 \mathrm{EY} \pm 0,3 \mathrm{EX}
\end{aligned}
$$

\section{2) Permodelan Struktur pada Software Staadpro V8i}

\section{a) Geometri Struktur}

Permodelan struktur bangunan beton bertulang pada Software Staadpro V8i (Alfredo ZH, Rafael HS, 2014) adalah menggunakan analisis portal 3 dimensi, seperti pada Gambar 4.

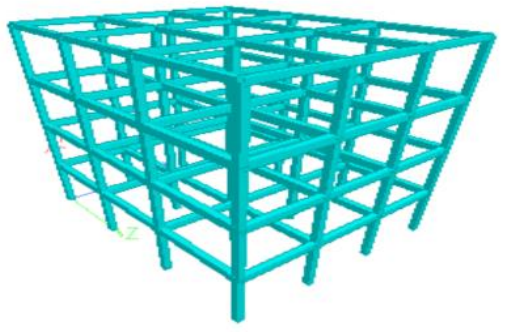

Portal 3D

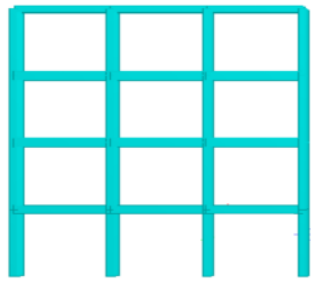

Portal arah X

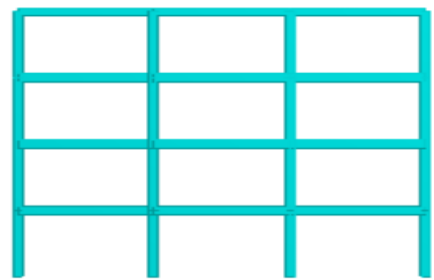

Portal arah Y

Gambar 4. Permodelan Struktur Beton Bertulang dengan Software Staadpro

\section{b) Input Dimensi Struktur (Section Property)}

Input dimensi struktur dapat dilihat pada Gambar 5.

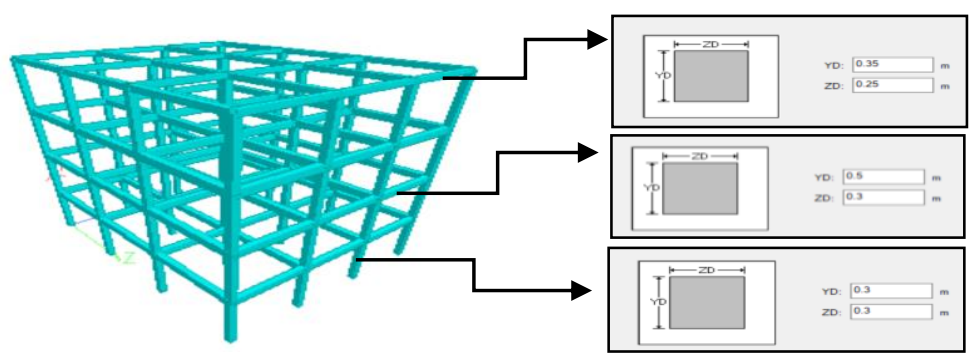

Gambar 5. Input dimensi balok, ringbalk, dan kolom 


\section{c) Input Perletakan Struktur (Support)}

Seluruh perletakan struktur dimodelkan perletakan jepit (fixed) yang dapat dilihat pada Gambar 6.

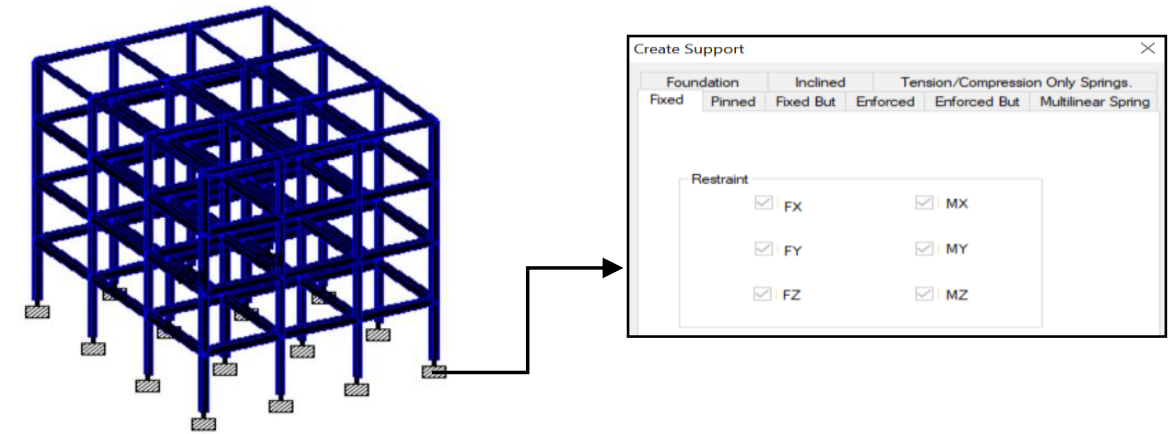

Gambar 6. Input perletakan struktur jepit (fixed)

\section{d) Input Pembebanan Struktur (Load)}

\section{Beban yang bekerja pada pelat lantai}

Input beban mati dan beban hidup yang bekerja pada pelat lantai menggunakan type beban FLOOR berupa beban merata segitiga dan trapesium, seperti pada Gambar 7.

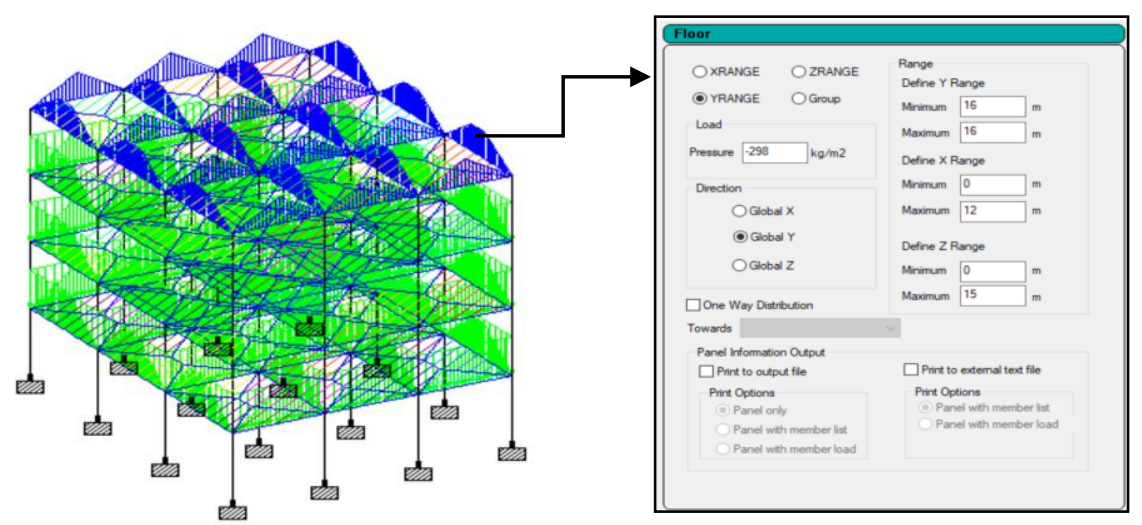

Gambar 7. Input beban yang bekerja pada pelat lantai

\section{Beban merata yang bekerja pada balok}

Input beban mati dan beban hidup yang bekerja pada balok menggunakan type beban UNIFORM FORCE berupa beban merata segiempat, seperti pada Gambar 7.

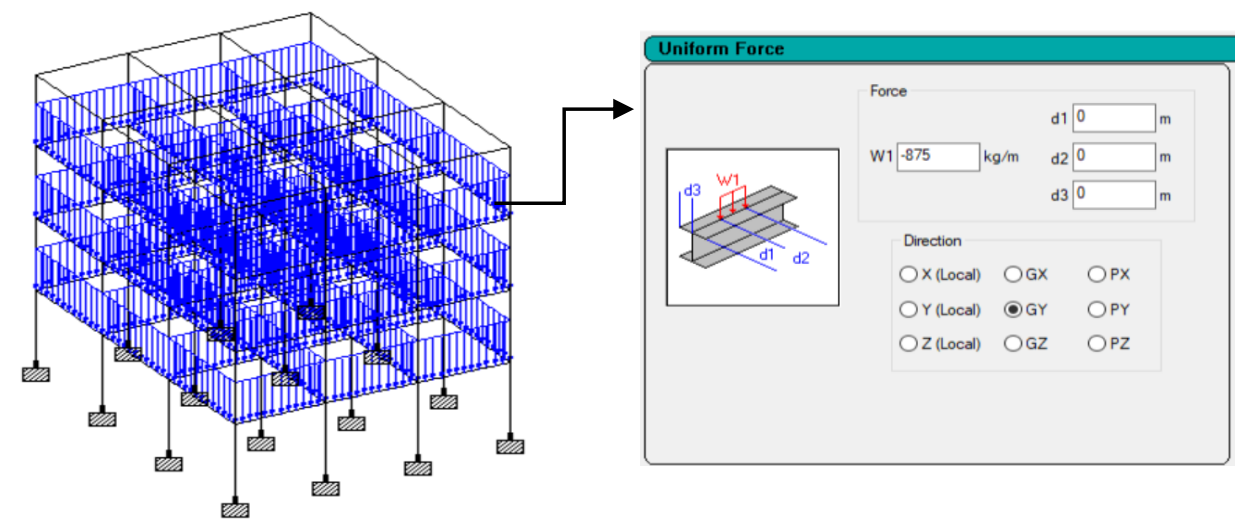

Gambar 8. Input beban yang bekerja pada balok 


\section{Beban Gempa Arah X}

Input beban gempa arah $\mathrm{X}$ berupa beban terpusat (NODAL LOAD) yang merupakan hasil dari analisis dengan metode statik ekivalen, beban terpusat bekerja pada setiap titik buhul portal sepanjang tinggi bangunan, seperti pada Gambar 8.

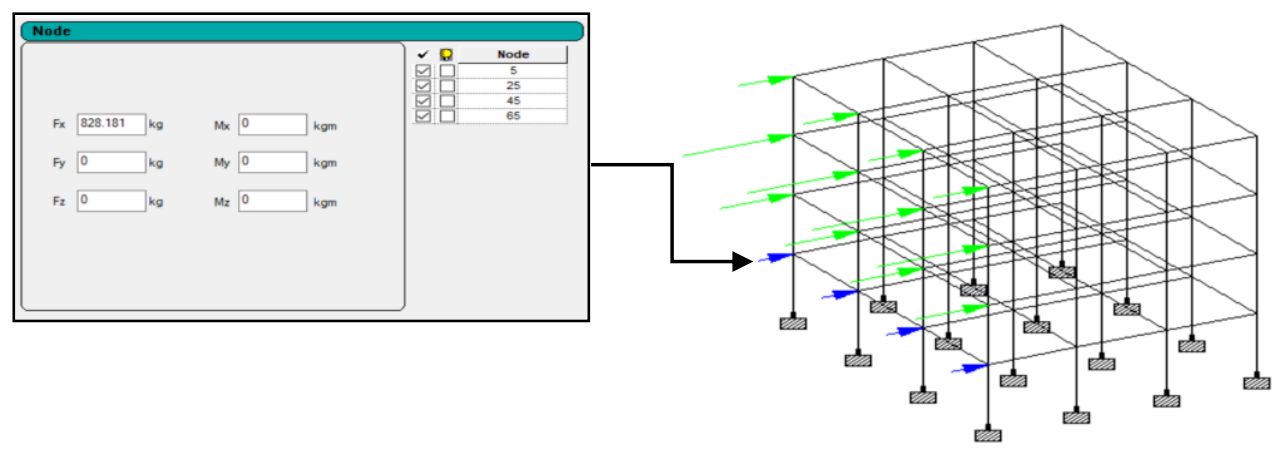

Gambar 9. Input beban gempa arah X

\section{Beban Gempa Arah Y}

Input beban gempa arah Y berupa beban terpusat (NODAL LOAD) yang merupakan hasil dari analisis dengan metode statik ekivalen, beban terpusat bekerja pada setiap titik buhul portal sepanjang tinggi bangunan, seperti pada Gambar 9.

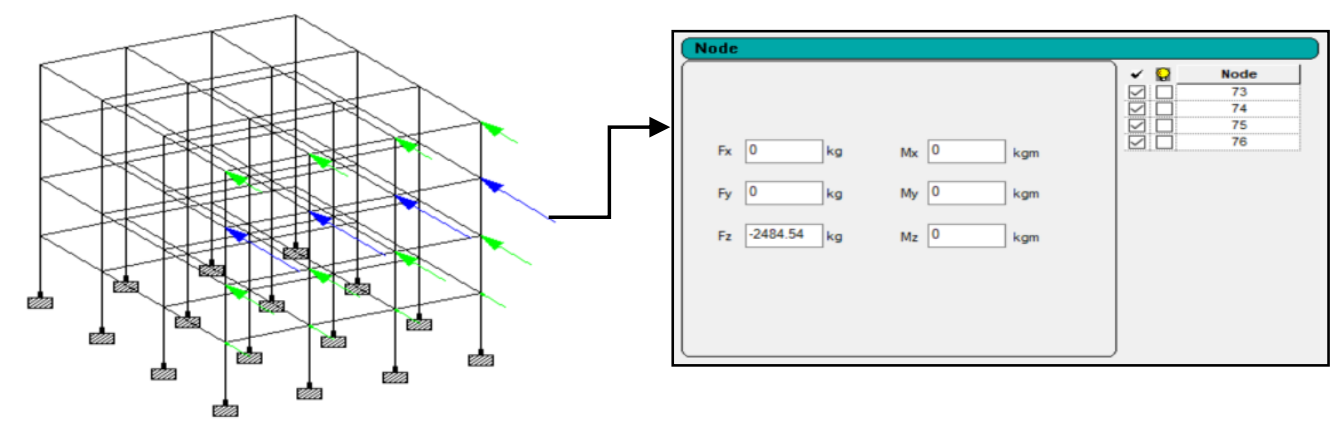

Gambar 10. Input beban gempa arah $Y$

\section{Kombinasi Pembebanan}

Input kombinasi pembebanan (Load Combination) yang merupakan kombinasi beban mati, hidup dan beban gempa arah X dan arah Y, serta beban kerja, seperti pada Gambar 10.

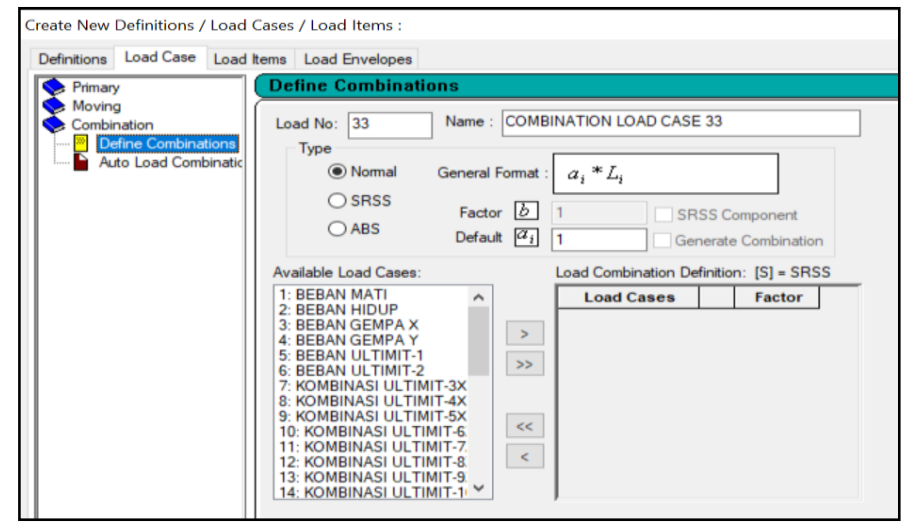

Gambar 11. Input kombinasi pembebanan (Load Combination) 
JURNAL KACAPURI

JURNAL KEILMUAN TEKNIK SIPIL

Volume 4 Nomor 1 Edisi Juni 2021

\section{3) Output Software Staadpro V8i}

\section{Gaya-gaya dalam struktur}

Output dari Gaya-gaya dalam struktur adalah berupa summary tabel gaya dan gambar gaya-gaya dalam momen, lintang dan normal, seperti pada Gambar 11.

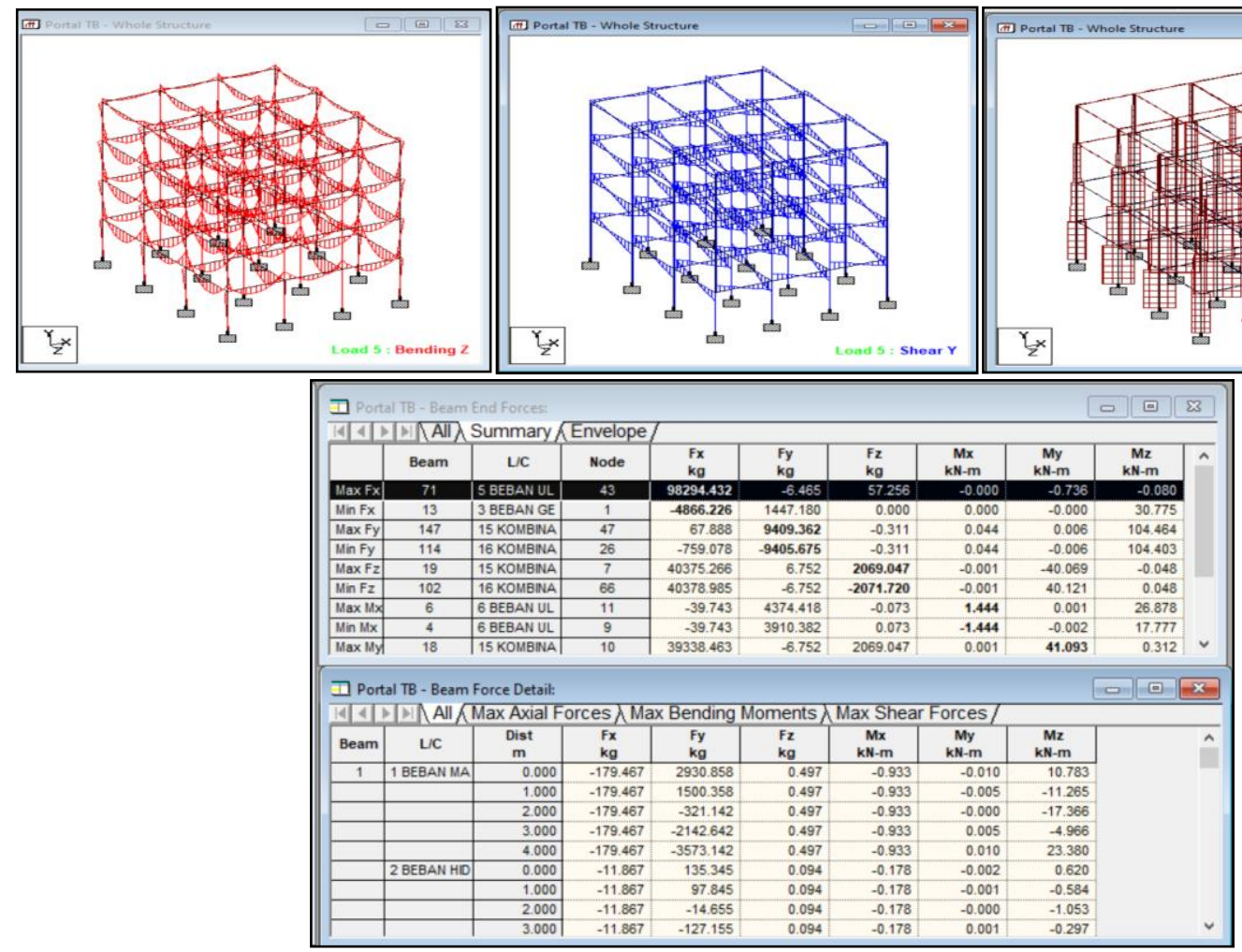

Gambar 12. Output Gaya-Gaya Dalam (Gaya Momen, Lintang, dan Normal)

\section{a) Deformasi Struktur}

Output dari deformasi struktur adalah berupa tabel summary deformasi dan gambar deformasi struktur, seperti pada Gambar 12.

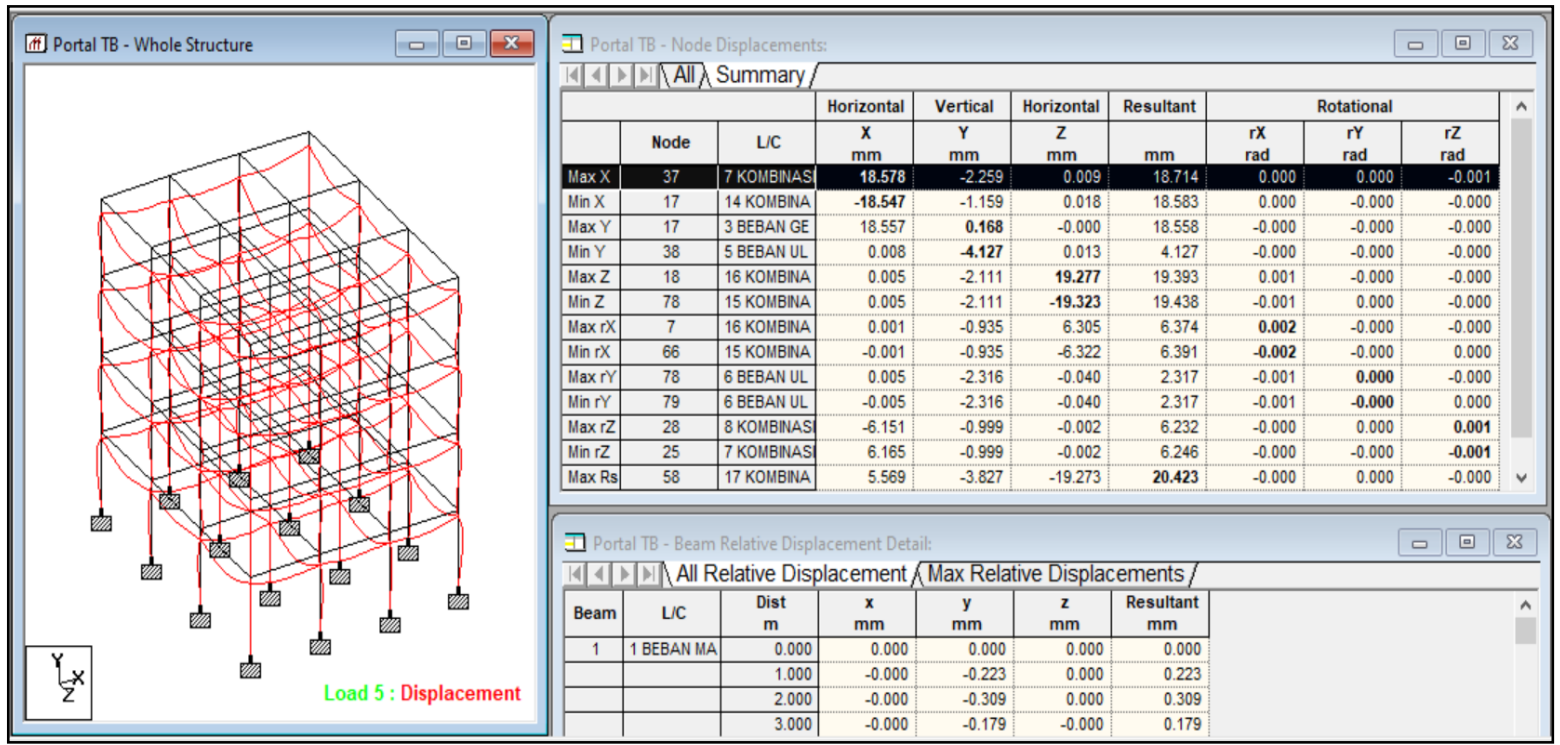

Gambar 13. Deformasi yang terjadi pada Struktur 


\section{Penulangan Elemen Struktur}

Output dari desain struktur adalah berupa gambar penulangan setiap elemen struktur seperti balok, dan kolom, contoh output gambar penulangan dapat dilihat pada Gambar 13 dan 14.

\section{Penulangan Balok}

Dalam contoh ini diperoleh penulangan balok sebagai berikut:

Tulangan lentur pada daerah tumpuan 5D12 dan 3D12

Tulangan lentur pada daerah lapangan 5D12 dan 3D12

Tulangan geser $8 \phi 10-222,95$ dibulatkan menjadi 8 $\$ 10-200$

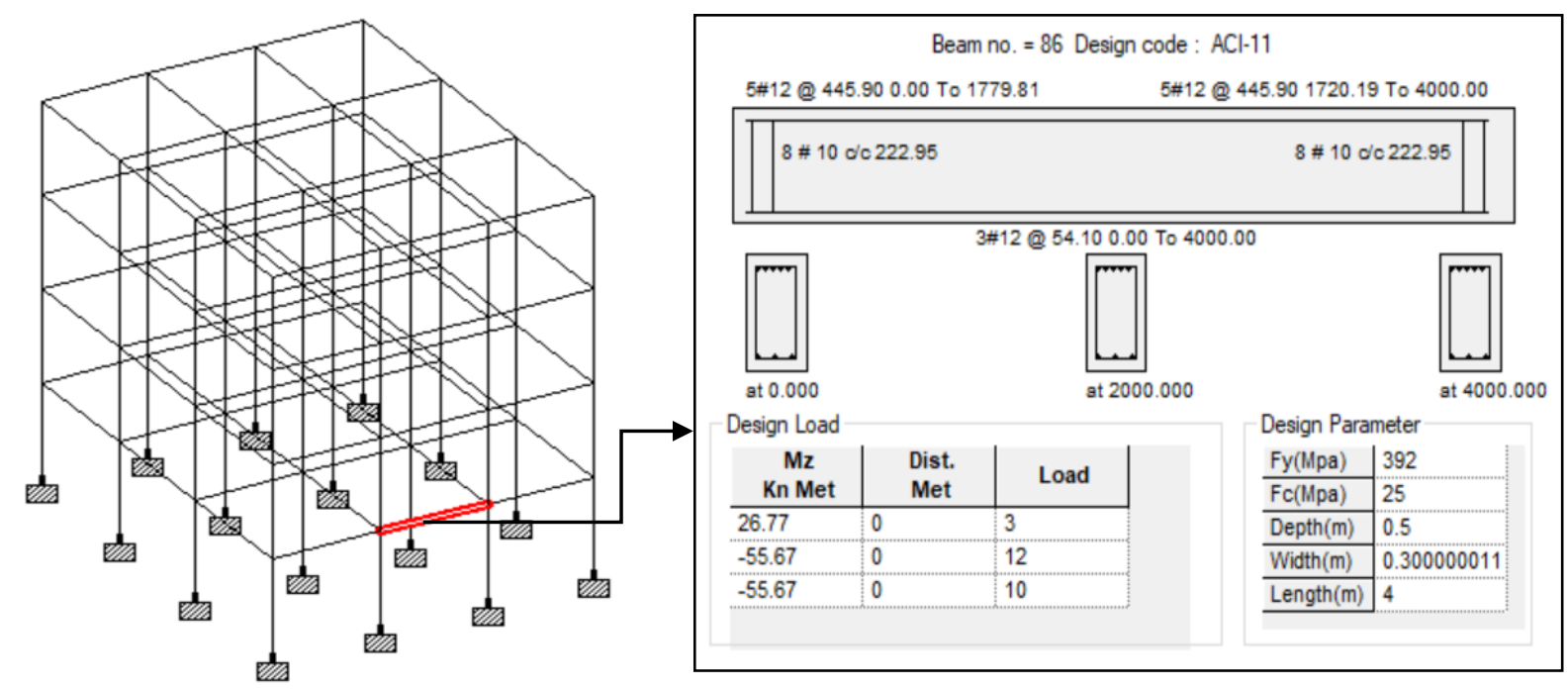

Gambar 14. Output gambar penulangan balok

\section{Penulangan Kolom}

Dalam contoh ini diperoleh penulangan kolom sebagai berikut:

Tulangan utama 8D12 dengan rasio penulangan $1 \%$.

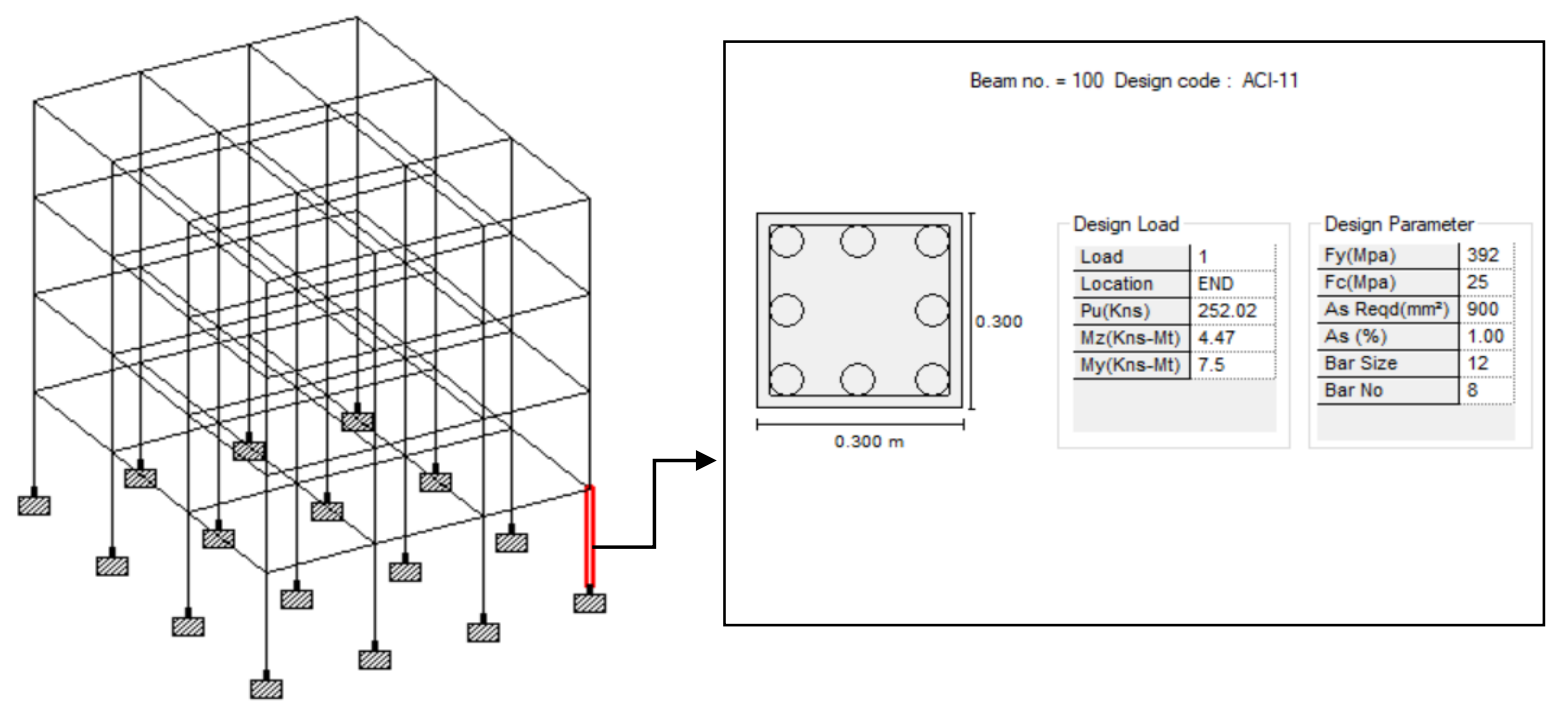

Gambar 15. Output gambar penulangan kolom 


\section{PENUTUP}

\section{Kesimpulan}

Dari hasil perancangan struktur beton bertulang yang menggunakan software Staadpro V8i dapat disimpulkan, sebagai berikut:

a) Gedung perkantoran mempunyai kategori resiko II sehingga termasuk dalam Kategori Desain Seismik $=\mathrm{C}$ dan Sistem Struktur yang diijinkan adalah Sistem Rangka Pemikul Momen Menengah (SRPMM).

b) Hasil output analisis struktur dari Software Staadpro berupa gaya-gaya dalam maksimum (momen, Lintang, dan normal) serta deformasi struktur.

c) Hasil output desain elemen struktur dari Software Staadpro berupa gambar penulangan beton dari setiap elemen balok dan kolom yang berdasarkan peraturan SNI 2847:2019.

\section{Saran}

Perlu kajian lebih lanjut mengenai:

a) Perancangan struktur beton bertulang secara 3D dengan langsung menggunakan elemen pelat lantai.

b) Perancangan struktur beton bertulang dengan memperhitungkan interaksi antara tanah dan struktur.

\section{Ucapan Terima Kasih}

Ucapan terima kasih kepada Program Magister Teknik Sipil Universitas Lambung Mangkurat yang telah memberikan bantuan dana sehingga terlaksananya bimbingan teknis pengabdian kepada masyarakat ini.

\section{DAFTAR PUSTAKA}

1. Adamo Z., Fernando F., Gianmario B. and Enzo M., 2020, On the Distribution in Height of Base Shear Forces in Linear Static Analysis of Base-Isolated Structures, Buildings 2020, 10, 197, MDPI, Basel, Switzerland.

2. Alfredo ZH, Rafael HS, 2014. Manual Staadpro V8i, Mexico.

3. Darmansyah T., 2018. Buku Ajar Struktur Beton Bertulang-II (HSKB-402) Edisi-2, ISBN: 978-602-6483-61-4.

4. Dirjen Cipta karya, 2021. Website Desain Spektra Indonesia, (online), http://rsa.ciptakarya.pu.go.id/2021/, diakses 05 Mei 2021

5. Finley A. C., 2015, Seismic Loads (Guide to the Seismic Load Provisions of ASCE 7-10), ASCE Press.

6. Himawan I, dkk., 2013, Aplikasi SNI Gempa 1726:2012, Semarang.

7. SNI 2847-2019. Persyaratan Beton Struktural Untuk Bangunan Gedung, BSN.

8. SNI 1726-2019.Tata Cara Perencanaan Ketahanan Gempa Untuk Struktur Bangunan Gedung dan Non Gedung, BSN.

9. SNI 1727-2013. Beban Minimum untuk Perancangan Bangunan Gedung dan Struktur Lain, BSN.

10. Yudha Lesmana, 2020. Handbook Desain Struktur Beton Bertulang berdasarkan SNI 2847:2019, Edisi Pertama, Makasar. 